\title{
PERBEDAAN KEMAMPUAN BERPIKIR KRITIS SISWA DALAM PEMBELAJARAN MATEMATIKA ANTARA MODEL PROBLEM BASED LEARNING DAN MODEL PEMBELAJARAN LANGSUNG KELAS IV SDN 95 KENDARI
}

\author{
Yosni Yorini Yusriani ${ }^{1)}$, Izlan Sentryo ${ }^{1)}$, Muhammad Yasin ${ }^{1)}$ \\ ${ }^{1)}$ Jurusan Pendidikan Guru Sekolah Dasar \\ FKIP Universitas Halu Oleo \\ email: yosniyoriniyusriani@yahoo.com, izlan.sentryo@gmail.com, \\ muhammad.yasin.unhalu@gmail.com
}

\begin{abstract}
Abstrak: Rumusan masalah dalam penelitian ini adalah: 1. Bagaimana kemampuan berpikir kritis siswa yang menerima model Problem Based Learning (PBL)? 2.Bagaimana kemampuan berpikir kritis siswa yang menerima model pembelajaran langsung? 3.Apakah ada perbedaan kemampuan berpikir kritis siswa dalam pembelajaran matematika antara model Problem Based Learning dan model pembelajaran langsung kelas IV SDN 95 Kendari?. Penelitian ini merupakan penelitian kuantitatif dengan menggunakan metode eksperimen dengan bentuk desain The Nonequivalent Pretest-Posttest Control Group Desaign Teknik pengambilan sampel yang digunakan adalah total sampling, yaitu keseluruhan populasi ditetapkan sebagai sampel penelitian. Oleh karena itu, sampel dalam penelitian ini yakni kelas Va sebagai kelas eksperimen dan kelas Vb sebagai kelas kontrol. Teknik pengambilan sampel dalam penelitian ini adalah purposive sampling yaitu teknik penentuan sampel dengan pertimbangan tertentu. Sampel dalam penelitian ini adalah kelas IVa sebagai kelas eksperimen yang diajar dengan model pembelajaran Problem Based Learning (PBL) yang berjumlah 30 siswa, dan kelas IVb sebagai kelas kontrol yang diajar dengan pembelajaran langsung berjumlah 30 siswa. Teknik pengumpulan data menggunakan instrumen tes yang terdiri dari pretest dan posttest. Teknik analisis data menggunakan analisis deskriptif dan analisis inferensial. Hasil penelitian menunjukkan bahwa ada perbedaan signifikan kemampuan berpikir kritis siswa dalam pembelajaran matematika antara model Problem Based Learning dan model pembelajaran langsung kelas IV SDN 95 kendari. Hal ini didasarkan pada nilai signifikan uji independent sample t-test diperoleh nilai diperoleh nilai $\mathrm{t}_{\text {hitung }}=5.725>\mathrm{t}_{\text {tabel }}=2.000$, dan signifikan 0,05 .
\end{abstract}

Kata Kunci: model pembelajaran problembased learning, model pembelajaran langsung, kemampuan berpikir kritis siswa.

\section{THE DIFFERENCE OF STUDENTS' CRITICAL THINKING ABILITY IN MATHEMATICAL LEARNING BETWEEN PROBLEM BASED LEARNING MODELS AND DIRECT LEARNING MODELS AT CLASS IV OF SDN 95 KENDARI}

\begin{abstract}
The formulation of the problem in this study was: 1. What is the critical thinking ability of students who accepted the Problem Based Learning (PBL) model? 2. What is the critical thinking ability of students who accepted the direct learning model? 3. Is there a difference on students' critical thinking skills in mathematics learning between the Problem Based Learning model and the direct learning model at class IV of SDN 95 kendari?. This research was a quantitative research by using an experimental method with the design form of the Nonequivalent Pretest-Posttest Control Group Desaign. The technique of sampling that used in this research was total sampling which meant that the entire population was determined as a research sample. The sample was taken by using purposive sampling which was the technique of determining the sample with certain considerations Therefore, the sample in this research was the Class VA (30 students) as an experimental class. It will be taught by using Problem Bases Learning (PBL) model. Then, the Class VB (30 students) as a control class. It will be taught by using direct learning model. Technique of data collection used test instruments which consisted of pretest and posttest. Technique of data analysis used descriptive analysis and inferential analysis. The results of this research showed that that there was a significant difference on students' critical thinking skills in mathematics learning between the Problem Based Learning model and the Direct Learning Model at the Grade IV of SDN 95 Kendari. It was based on the significant value of the independent sample t-test, the value obtained $t$-count $=5.725>t$-table $=2,000$, and significant was 0.05 .
\end{abstract}

Keywords: problem based learning model, direct learning model, students' critical thinking ability 


\section{Pendahuluan}

Mengajarkan dan mengembangkan kemampuan berpikir kritis dipandang sebagai sesuatu yang sangat penting untuk dikembangkan di sekolah agar siswa mampu dan terbiasa menghadapi berbagai permasalahan di sekitarnya. Menurut Cabera, penguasaan kemampuan berpikir kritis tidak cukup dijadikan sebagai tujuan pendidikan semata, tetapi juga sebagai proses fundamental yang memungkinkan siswa untuk mengatasi berbagai permasalahan masa mendatang di lingkungannya. Untuk itu dalam proses belajar mengajar guru tidak boleh mengabaikan penguasaan kemampuan berpikir kritis siswa (Ikhsan \& Rizal, 2014, p.72).

Berdasarkan hasil wawancara langsung dengan guru kelas IV SDN 95 Kendari pada tanggal 07 Januari 2019, peneliti memperoleh informasi bahwa hasil belajar siswa pada mata pelajaran Matematika masih belum sesuai dengan apa yang diharapkan oleh guru kelas IV SDN 95 Kendari. Hal ini disebabkan karena pada saat proses belajar mengajar siswa lebih banyak bermain dari pada belajar, akhirnya guru dalam mengajar lebih banyak menggunakan metode ceramah sehingga pada saat proses pembelajaran rasa ingin tahu siswa kurang, hal ini menimbulkan kurang aktifnya siswa untuk melakukan proses pembelajaran, guru dan buku menjadi satu-satunya sumber belajar, guru mentransfer ilmu dan siswa menerimanya, tidak ada umpan balik pada proses pembelajaran, hal ini membuat siswa bosan. Kemudian guru menunjukkan nilai raport siswa tahun ajaran 2018/2019 Semester I dimana Kriteria Ketuntasan Minimal (KKM) yaitu 65 dan rata-rata hasil ulangan siswa yaitu dan persentase ketuntasan $65 \%$ dari 30 siswa, 18 siswa yang mencapai Kriteria Ketuntasan Minimal (KKM) dan 12 siswa tidak mencapai Kriteria Ketuntasan Minimal (KKM). Model pembelajaran yang digunakan guru seharusnya dapat membantu proses analisis dan berpikir kritis matematis siswa permasalahan tersebut adalah model Problem Based Learning $(P B L)$.

Baker dalam Amir (2015, p.160) menjelaskan berpikir kritis digunakan seseorang dalam pr oses kegiatan mental seperti mengidentifikasi pusat masalah dan asumsi dalam sebuah argumen, membuat simpulan yang benar dari data, membuat simpulan dari informasi atau data yang diberikan, menafsirkan apakah kesimpulan dijamin berdasarkan data yang diberi kan, dan mengevaluasi bukti atau otoritas. Menurut Ennis dalam Susanti, dkk (2019, p.58) menjelaskan bahwa kemampuan berpikir kritis melatih siswa untuk mencermati, menganalisis dan mengevaluasi informasi atau pendapat sebelum menentukan menerima atau menolak informasi tersebut. Senada dengan hal tersebut, Yaumi dalam Haryanti (2017, p.58) mengemukakan bahwa "berpikir kritis adalah kemampuan kognitif untuk mengatakan sesuatu dengan penuh keyakinan karena bersandar pada alasan yang logis dan bukti empiris yang kuat."

Hmelo-Silver, Serafino \& Cicchelli dalam Maqbullah, dkk (2018, p.107) mengemukakan bahwa "Problem Based Learning adalah seperangkat model mengajar yang menggunakan masalah sebagai fokus untuk mengembangkan keterampilan pemecahan masalah, materi, dn pengetahuan diri." Menurut Barrow (2010) pemberian masalah dalam Problem Based learning (PBL) harus memperhatikan dan memahami jenis masalah yang diberikan. Kurang berminatnya siswa dalam belajar matematika perlu diberikan pengalaman belajar otentik dan kemampuan pemecahan masalah. Pengalaman pengalaman atau pembelajaran yang memberikan kesempatan kepada siswa memperoleh kemampuan pemecahan masalah dapat merangsang kemampuan berpikir kritis siswa. Pada model Problem Based Learning (PBL), siswa pertama dihadapkan dengan masalah illstructured, open-ended, ambigu, dan kontekstual. Agar dapat memecahkan masalah, siswa harus mempelajari materi terlebih dahulu. Artinya, siswa harus mengkonstruksi pengetahuan melalui proses penemuan. Setelah siswa memahami materi yang terkait dengan masalah, siswa selanjutnya memecahkan masalah yang dihadapi. Dalam proses pemecahan masalah, siswa bekerja dalam kelompok (Redhana, 2012, p.353).

Penelitian yang pernah dilakukan Sianturi, A., Sipayung, T. N., \& Argareta, M. (2018). Pengaruh Model Problem Based Learning (PBL) Terhadap Kemampuan Berpikir Kritis Matematis Siswa SMPN 5 Sumbul. Hasil penelitian menunjukkan bahwa kemampuan berpikir kritis matematis siswa yang mengikuti pembelajaran dengan model Problem Based Learning (PBL) lebih tinggi dibandingkan dengan siswa yang mengikuti pembelajaran konvensional. Berdasarkan uji hipotesis diperoleh nilai thitung $=2,59$ dan ttabel $=1,672$ dengan $\mathrm{dk}=58$ dan taraf signifikansi 
sehingga terlihat bahwa>yaitu 2,59 > 1,672. Jadi, dapat disimpulkan bahwa model Problem Based Learning berpengaruh terhadap kemampuan berpikir kritis matematis siswa. Penelitian yang relevan pernah dilakukan oleh Dasa Ismaimuza (2010) dalam penelitiannya yang berjudul "Pengaruh Pembelajaran Berbasis Masalah dengan Strategi Konflik Kognitif terhadap Kemampuan Berpikir Kritis Matematis dan Sikap Siswa SMP", menyimpulkan bahwa kemampuan berpikir kritis matematis siswa yang memperoleh Pembelajaran Berbasis Masalah dengan Strategi Konflik Kognitif lebih baik dari pada siswa yang memperoleh pembelajaran konvensional, kemudian sikap siswa yang diajar dengan pembelajaran PBL lebih positif dibandingkan dengan sikap siswa yang diajar dengan pembelajaran konvensional. Pengajaran langsung digunakan untuk menyampaikan pelajaran yang ditranformasikan langsung oleh guru kepada siswa. Menurut Trianto dalam Kurniasih (2016, p.277) mengemukakan bahwa "Penyusunan waktu yang digunakan untuk mencapai tujuan pembekajaran harus efisien mungkin, sehingga guru dapat merancang dengan waktu yang digunakan." Kardi dan Nur dalam Asmah (2018, p.111) menyatakan bahwa "pembelajaran langsung adalah suatu pendekatan mengajar yang dapat membantu siswa mempelajari keterampilan dasar dan memperoleh informasi yang dapat diajarkan secara bertahap."

Berdasarkan latar belakang yang dikemukakan di atas maka penulis tertarik untuk melaksanakan penelitian tentang: "Perbedaan Kemampuan Berpikir Kritis Siswa Dalam Pembelajaran Matematika Antara Model Problem Based Learning Dan Model Pembelajaran Langsung Kelas IV SDN 95 Kendari”.

\section{Metode Penelitian}

Penelitian ini menggunakan desain penelitian the nonequivalent pretest-posttest control group desaign. populasi dalam penelitian ini yaitu seluruh siswa SD Negeri 95 Kendari, dengan jumlah siswa 421 siswa, dimana siswa laki-laki berjumlah 206 dan siswa perempuan berjumlah 215 siswa. sampel dalam penelitian ini yakni kelas IVa sebagai kelas eksperimen yang diajar dengan model Problem Based Learning (PBL) yang berjumlah 30 siswa, kelas IVb sebagai kelas kontrol yang diajar dengan pembelajaran langsung berjumlah 30 siswa. Teknik Pengumpulan data yang digunakan dalam penelitian ini berupa teknik pemberian tes yang diberikan pada kelas eksperimen dan kelas kontrol dalam bentuk tertulis. Teknik analisis data pada penelitian ini menggunakan program computer SPSS for windows dengan tingkat kepercayaan $95 \%$

\section{Hasil Penelitian}

\section{Hasil Uji coba Instrumen}

a) Dari uji validitas butir soal kemampuan berpikir kritis matematis siswa diperoleh butir soal yang valid sebesar 4 soal, yang disajikan pada diagram 1. dibawah ini.

Tabel 1. Analisis Validitas Instrumen Kemampuan Berpikir Kritis Siswa

\begin{tabular}{|c|c|c|}
\hline Butir Soal & Koefisien Korelasi & Keterangan \\
\hline 1 & 0,836 & Valid \\
\hline 2 & 0,539 & Valid \\
\hline 3 & 0,504 & Valid \\
\hline 4 & 0,626 & Valid \\
\hline
\end{tabular}

b) Dari uji reliabilitas soal kemampuan berpikir kritis matematis siswa diperoleh butir soal tes yang reliabel, disajikan pada tabel 2 . berikut ini.

Tabel 2. Analisis Reliabilitas Kemampuan Berpikir Kritis Siswa

\begin{tabular}{|c|c|}
\hline Koefisien Reliabilitas & Keterangan \\
\hline 0,835 & Reliable \\
\hline
\end{tabular}

Berdasarkan hasil analisis validitas dan reliabilitas instrument diatas maka diperoleh masing-masing koefisien korelasi berada pada kategori sedang atau cukup baik, sehinga layak digunakan untuk mengukur kemampuan berpikir kritis siswa. Instrumen ini dinyatakan layak untuk digunakan dari hasil validator ahli yaitu Dr. Izlan Sentryo, M.Pd. hal ini sesuai dengan hasil 
validitas instrument disekolah lain yang memiliki karakteristik yang sama dengan sekolah yang akan diteliti.

\section{Hasil Analisis Deskriptif}

a. Data Hasil Penelitian Kemampuan Berpikir Kritis Siswa Kelas Eksperimen Yang Menggunakan Model Problem Based Learning

Data hasil penelitian pada kelas eksperimen yang menggunakan model Problem Based Learning (PBL) menghasilkan data klasifikasi N-Gain yang disajikan pada diagram 1. dibawah ini

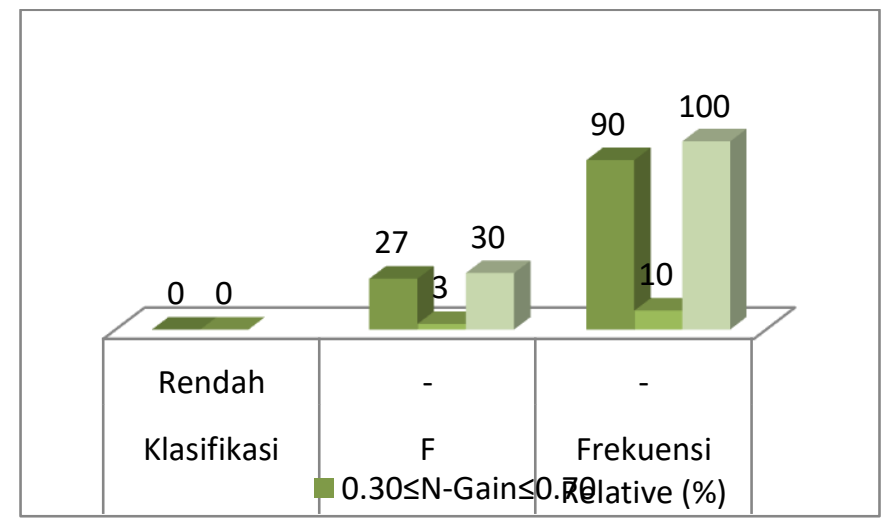

Berdasarkan diagram 1. diketahui nilai N-Gain pada kelas eksperimen klasifikasi rendah tidak ada dan klasifikasi sedang yaitu pada interval $0.30 \leq \mathrm{N}$-Gain $\leq 0.70$ dengan jumlah 27 siswa atau sebesar $90 \%$ sedangkan klasifikasi yang tinggi yaitu pada interval NGain $\geq 0.70$ dengan jumlah 3 siswa atau sebesar $10 \%$.

\section{b. Data Hasil Penelitian Kemampuan Berpikir Kritis Siswa Yang Menggunakan Pembelajaran Langsung}

Data hasil penelitian pada kelas kontrol yang menggunakan pembelajaran langsung menghasilkan data klasifikasi N-Gain yang disajikan pada diagram, dibawah ini.

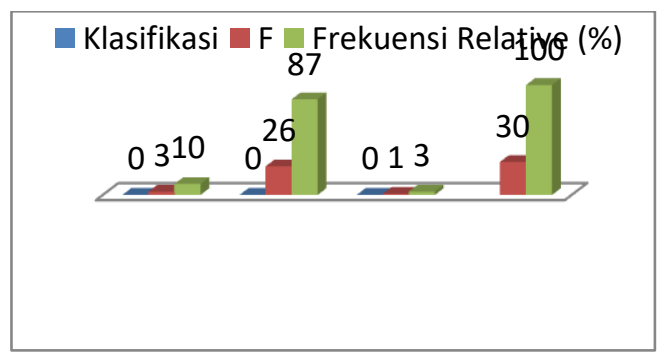

Berdasarkan diagram 4.4 diketahui nilai N-Gain kelas kontrol klasifikasi yang sedang dan rendah merupakan klasifikasi terbesar yaitu pada interval NGain pada 0.30 dengan jumlah siswa 3 orang aau sebesar $10 \%$ dan interval dan interval $0.30 \leq \mathrm{N}$-Gain $\leq 0.70$ dengan jumlah siswa 26 orang atau sebesar $87 \%$. Sedangkan klasifikasi yang tinggi yaitu pada interval N-Gain $>0.70$ dengan jumlah siswa 1 orang atau sebesar 3\%. Berikut ini disajikan diagram frekuensi dan klasifikasi N-Gain kemampuan berpikir kritis siswa yang menggunakan pembelajaran langsung.

\section{c. Analisis Deskriptif Kemampuan Berpikir Kritis Siswa Kelas Eksperimen Dan Kelas Kontrol}

Hasil penelitian ini tentang kemampuan berpikir kritis siswa, berdasarkan data klasifikasi $\mathrm{N}$-Gain di kelas eksperimen dan kelas kontrol memiliki perbedaan. Perbedaan tersebut terdapat pada nilai mean, median, modus, variance, standar deviasi, minimum dan maximum. Pada kelas 
eksperimen dengan jumlah data 30 siswa, diperoleh rata-rata $\mathrm{N}$-Gain 0.5873 dengan standar deviasi sebesar 0.09223 , nilai tengah 0.5851 , modus 0.64 minimumnya 0.40 dan maximumnya 0.76 . Sedangkan pada kelas kontrol dengan jumlah data 30 siswa, diperoleh nilai rata-rata sebesar 0.4156 dengan standar deviasi sebesar 0.13593 , nilai tengah 0.4283 , modus 0.049 nilai minimumnya 0.09 dan maximumnya 0.74 . Nilai rata-rata $\mathrm{N}$-Gain yang diperoleh pada dua kelompok menunjukkan bahwa nilai 0.5873 tersebut mewakili nilai $\mathrm{N}$-Gain 30 siswa pada kelas eksperimen dan Nilai 0.4156 mewakili nilai N-gain 30 siswa pada kelas kontrol.

\section{Hasil Analisis Inferensial}

a. Uji Normalitas

Dalam menguji normalitas data, statistic yang digunakan adalah uji analisis nonparametric 1 sample Kolmogrov Sminor dengan menggunakan IBM SPSS version 15. Untuk pengambilan keputusan apakah data normal atau tidak maka cukup membaca pada nilai signifikan Asymp.Sig. (2-tailed). Jika signifikan kurang dari 0,05 maka kesimpulannya data berdistribusi tidak normal. Jika signifikannya lebih dari 0,05 maka data berdistribusi normal. (Sundayana, 2017:90). Pada tabel 4.6 diketahui bahwa nilai Asymp. Sig. (2-tailed) $0.902>0.05$ maka H0 diterima, sehingga sebaran data pada kelas eksperimen dan kelas kontrol berdistribusi normal.

b. Uji Homogenitas

Uji homogenitas dilakukan untuk mengetahui varian populasi data antara dua kelompok atau lebih, apakah data memiliki varians yang sama atau berbeda. Uji ini sebagai prasyarat dalam uji hipotesis yaitu uji F. hasil perhitungan uji homogenitas dengan taraf signifikan $=0.05$ dapat diketahui bahwa nilai signifikan > $0.05(0.250>0.05)$, dapat disimpulkan bahwa varian kelompok kelas eksperimen dan kelas Kontrol memiliki varian homogen.

c. Uji hipotesis

Setelah melakukan uji prasyarat maka diperoleh data N-Gain pada kelas eksperimen dan kelas kontrol berdistribusi normal dan bervarians homogen. Maka akan dilakukan penggujian perbedaan kemampuan berpikir kritis siswa dalam pembelajaran matematika antara model Problem Based Learning (PBL) dan pembelajaran langsung, dengan uji statistic independent sample t-test untuk menguji perbedaan rata-rata dua kelompok data yang independen.

hasil uji-t diperoleh nilai $\mathrm{t}_{\text {hitung }} \quad=5.725>\mathrm{t}_{\text {tabel }}=2.000$, dan signifikan $\alpha=0,05$, nilai $\frac{\text { sign(2-tailed })}{2}=\frac{0.000}{2}=0<0.05$, maka $\mathrm{H}_{0}$ ditolak dan $\mathrm{H}_{1}$ diterima. Hal ini berarti terdapat perbedaan signifikan kemampuan berpikir kritis siswa dalam pembelajaran matematika antara model Problem Based Learning dan model pembelajaran langsung kelas IV SDN 95 Kendari.

\section{Pembahasan}

\section{Kemampuan berpikir kritis siswa yang menerima model pembelajaran Problem Based Learning (PBL).}

Berdasarkan hasil analisis deskriptif, diperoleh nilai rata-rata $\mathrm{N}$-Gain sebesar 0,5873 artinya kemampuan berpikir kritis matematis siswa dikelas eksperimen tergolong sedang dengan standar deviasinya yaitu 0.09223 yang menunjukkan bahwa besar penyimpangan data dari rata-rata kelas eksperimen cukup kecil.

Dalam pembelajaran dengan model Problem Based Learning (PBL) siswa mengerjakan permasalahan yang terdapat dalam LKPD yang diberikan peneliti secara berkelompok dengan jumlah ada 7 kelompok setiap kelompok berjumlah 4 atau 5 orang siswa yang secara heterogen. Dalam kelompok, permasalahan yang terdapat di LKPD dikerjakan melalui diskusi kelompok, siswa secara tidak langsung memiliki keterampilan untuk menyelesaikan masalah secara mandiri. Hal ini sejalan dengan pernyataan Ward (2002) mengemukakan bahwa Problem Based Learning (PBL) adalah suatu model pembelajaran yang melibatkan siswa untuk menyelesaikan suatu masalah melalui tahap-tahap metode ilmiah sehingga siswa dapat mempelajari pengetahuan yang berhubungan dengan masalah tersebut sekaligus memiliki keterampilan untuk menyelesaikan masalah (Lestari \& Yudhanegara, 2017, p.42). Dalam model pembelajaran problembased learning (PBL) siswa dituntut untuk menyelesaikan masalah yang terdapat pada LKPD dan diberi kesempatan untuk saling berkolaborasi, berbagi pengetahuan dengan teman sekelompoknya. Kegiatan diskusi kelompok dapat merangsang kemampuan berpikir kritis matematis siswa yang 
relative tinggi dapat lebih memantapkan pemahaman dalam memecahkan suatu permasalahan.Sedangkan siswa yang kemampuan rendah dapat memperoleh pemaham yang lebih baik dengan melalui penjelasan dengan teman sekelompoknya yang memiliki kemampuan tinggi.Dengan adanya diskusi kelompok dapat mengurangi kesalahan pemahaman seseorang terhadap suatu masalah.kesalah pahaman ini membuat siswa mengalami kesulitan dalam mengerjakan soal yang diberikan oleh peniliti sehingga mengakibatkan jawaban tidak sesuai dengan apa yang diharapkan. Pada tahap mengembangkan dan menyajikan hasil karya siswa perwakilan dari kelompok mempersentasikan jawabanya didepan kelas dan kelompok lain memperhatikan apa yang dipersentasikan. Apa bila terdapat hal yang tidak dimengerti dan kelompok lain memeliki jawaban yan lain maka kelompok tersebut diberikan kesempatan untuk bertanya dan menyampaikan jawabannya. Senada dengan hal tersebut, Rahmawati, dkk (2014, p.36) mengemukakan bahwa skor siswa yang mendapatkan pembelajaran model PBL pada kelas eksperimen lebih tinggi dibandingkan dengan siswa pada kelas control yang menggunakan model pembelajaran konvensional.

\section{Kemampuan berpikir kritis siswa yang menerima model pembelajaran langsung.}

Berdasarkan hasil analisis deskriptif, diperoleh nilai rata-rata $\mathrm{N}$-Gain 0,4156 artinya kemampuan berpikir kritis matematis siswa di kelas kontrol cukup meningkat dan standar deviasinya sebesar 0,13593 yang menunjukkan bahwa besar penyimpangan data dari rata-rata kelas cukup kecil. Pembelajaran dikelas kontrol dilaksanakan selama 4 kali pertemuan, dengan menggunakan model pembelajaran langsung dimana siswa mengerjakan latihan soal-soal yang diberikan guru. Pembelajaran semacam ini menyebabkan guru mendominasi kegiatan belajar mengajar, sementara siswa hanya menjadi pendengar dan pencatat yang baik. Hasilnya adalah siswa yang kurang mandiri tidak berani mengemukakan pendapat sendiri, selalu meminta bimbingan guru dan kurang gigih dalam menyelesaikan masalah matematika, sehingga pengetahuan yang dimiliki siswa hanya sebatas apa yang diberikan guru. Selain itu pembelajaran yang disampaikan guru kurang memberikan pengalaman belajar yang menyenangkan dan menggali potensi, serta rasa ingin tau siswa. Pembelajaran langsung menempatkan guru sebagai sumber informasi segala-galanya sehingga siswa di cetak pengetahuannya seperti pengetahuan yang dikuasai oleh guru-gurunya dan jika soalnya diganti sedikit saja maka mereka akan kesulitan dalam mengerjakannya, sehingga ketika diberi masalah dia hanya dapat menyelesaikan masalah tersebut sesuai dengan apa yang dikatakan oleh guru, Siswa sering diposisikan sebagai orang yang tidak tahu apa-apa, yang hanya menunggu apa yang guru berikan. Pada model pembelajaran langsung penyajian informasi dengan metode ceramah dan Tanya jawab. Pembelajaran langsung masih didasarkan pada guru menyajikan materi/mentransfer informasi secara langsung dan terstruktur. Hal ini senada dengan apa yang diungkapkan oleh Dufresne et al. bahwa pembelajaran langsung selama ini lebih ditekankan pada tugas seorang guru untuk memberikan intruksi atau ceramah selama proses pembelajaran berlangsung, sementara siswa mendengarkan secara pasif (Ni Nyoman Sri Lestari, 2012, p.11).

\section{Perbedaan kemampuan berpikir kritis siswa dalam pembelajaran matematika antara model problem based learning dan model pembelajaran langsung kelas IV SDN 95 kendari.}

Untuk mengetahui perbedaan kemampuan berpikir kritis siswa yang diberi model Problem Based Learning (PBL) dan kemampuan berpikir kritis siswa yang diberi model pembelajaran langsung. maka dilakukan uji hipotesis untuk mendapatkan rata-rata nilai $\mathrm{N}$-Gain kemampuan berpikir kritis pada dua kelas dengan menggunakan statistic independent sample test. Dengan terlebih dahulu melakukan uji prasyarat yaitu uji normalitas dan uji homogenitas kelas eksperimen dan kelas kontrol.

Berdasarkan uji normalitas data dengan menggunakan uji I sample Kolmogrov Siminor diperoleh data kemampuan berpikir kritis siswa kelas eksperimen dan kelas kontrol berdistribusi normal. Selanjutnya berdasarkan uji homogenitas varians data kedua kelompok bersifat homogen.Kemudian untuk pengujian hipotesis dengan menggunakan uji independent sample t-test 
yang digunakan untuk menguji perbedaan rata-rata dua kelompok data yang independen. Dari pengujian hipotesis tersebut, diperoleh nilai $\mathrm{t}_{\text {hitung }}=5.725>\quad=\mathrm{t}_{\text {tabel }} 2.000$, dan signifikan $\alpha=$ 0,05 nilai $\left(\frac{\operatorname{sign}(2-\text { tailed })}{2}\right)=\frac{0.000}{2}=0<0.05$, maka $\mathrm{H}_{0}$ ditolak dan $\mathrm{H}_{1}$ diterima. Hal ini berarti terdapat perbedaan signifikan kemampuan berpikir kritis siswa dalam pembelajaran matematika antara model problem based learning dan model pembelajaran langsung kelas IV SDN 95 kendari. Hasil penelitian ini sejalan dengan hasil penelitian Sianturi (2018) yang menemukan bahwa kemampuan berpikir kritis siswa yang mengikuti pembelajaran dengan model Problem Based Learning (PBL) lebih tinggi dibandingkan dengan siswa yang mengikuti pembelajaran konvensional dengan judul penelitian "Pengaruh Model Problem Based Learning Terhadap Kemampuan Berpikir Kritis Matematis Siswa SMPN 5 Sumbul". Hal ini menunjukkan bahwa model Problem Based Learning (PBL) berpengaruh terhadap kemampuan berpikir kritis siswa. Menurut Arends dalam Ningsih, dkk (2018, p.1588) mengemukakan melalui pengalaman nyata kemampuan berpikir kritis, kemandirian dan percaya diri siswa akan meningkat

Berdasarkan analisis hasil penelitian sebelumnya dan hasil uji hipotesis pada penelitian ini dapat diketahui bahwa kemampuan berpikir kritis siswa pada kelas eksperimen dengan menggunakan model Problem Based Learning (PBL) lebih baik dari pada kelas kontrol yang menggunakan pembelajaran langsung. Sehingga dapat disimpulkan bahwa ada perbedaan signifikan kemampuan berpikir kritis siswa dalam pembelajaran matematika antara model problem based learning dan model pembelajaran langsung kelas IV SDN 95 kendari.

\section{Simpulan}

Berdasarkan hasil penelitian yang telah diuraikan di BAB IV dapat disimpulkan bahwa ada perbedaan signifikan kemampuan berpikir kritis siswa dalam pembelajaran matematika antara model problem based learning dan model pembelajaran langsung kelas IV SDN 95 kendari. Hal ini didasarkan pada nilai signifikan uji independent sample t-test diperoleh nilai diperoleh nilai $\mathrm{t}_{\text {hitung }}=$ $5.725>\mathrm{t}_{\text {tabel }}=2.000$, dan signifikan 0,05 nilai $\left(\frac{\operatorname{sign}(2-\text { tailed })}{2}\right)=\frac{0.000}{2}=0<0.05$, maka $\mathrm{H}_{0}$ ditolak dan $\mathrm{H}_{1}$ diterima. Hal ini berarti terdapat perbedaan signifikan kemampuan berpikir kritis siswa dalam pembelajaran matematika antara model problem based learning dan model pembelajaran langsung kelas IV SDN 95 kendari.

\section{Daftar Pustaka}

Amir, M.F. (2015). Proses Berpikir Kritis Siswa Sekolah Dasar Dalam Memecahkan Masalah Berbentuk Soal Cerita Matematika Berdasarkan Gaya Belajar. Jurnal Math Educator $\begin{array}{lllll}\text { Nusantara } & \text { Volume } & 01 & \text { Nomor } & 02,\end{array}$ https://ojs.unpkediri.ac.id/index.php/matematika/article/download/235/150

Asmah. (2018). Penerapan Model Pembelajaran Langsung Untuk Meningkatkan Hasil Belajar Matematika Siswa Kelas II SD Negeri 016 Buluh Kasap. Jurnal PAJAR (Pendidikan dan Pengajaran) Program Studi Pendidikan Guru Sekolah Dasar FKIP Universitas Riau, Volume 1 Nomor 1, 110-114. https://www.researchgate.net/publication/331759611

Haryanti, Y.D. (2017). Model Problem Based Learning Membangun Kemampuan Berpikir Kritis Siswa Sekolah Dasar. Jurnal Cakrawala Pendas Vol. 3 No.2, 57-63. https://media.neliti.com/media/publications/266400-model-problem-based-learning$\underline{\text { membangun-k-0b165afb.pdf }}$

Kurniasih, T. (2016). Penerapan Model Pembelajaran Langsung Untuk Meningkatkan Hasil Belajar IPA Siswa Kelas I SDN 006 Tri Mulya Jaya. Jurnal Primary Program Studi Pendidikan Guru Sekolah Dasar Fakultas Keguruan dan Ilmu Pendidikan Universitas Riau, Volume 5, Nomor 3, 275-287. https://media.neliti.com/media/publications/258386penerapan-model-pembelajaran-langsung-un-c08061f2.pdf 
Maqbullah, S., Tati, S., \& Muqodas, I. (2018). Penerapan Model Problem Based Learning Untuk Meningkatkan Kemampuan Berpikir Kritis Pada Pembelajaran Ipa Di Sekolah Dasar. Metodik Didaktik: $\quad$ Vol. 13 No. 2, 106-112. https://ejournal.upi.edu/index.php/MetodikDidaktik/article/download/9500/6086

Ni, Nyoman, Sri Lestari. (2012). Pengaruh Model Pembelajaran Berbasis Masalah (Problem Based Learning) Dan Motivasi Belajar Terhadap Prestasi Belajar Fisika Bagi Siswa Kelas VII SMP. Universitas Pendidikan Ganesha Singaraja: Program Studi Teknologi Pembelajaran Program Pasca Sarjana.

Ningsih, PR., Arif, H., \& Kusairi, S. (2018). Penerapan Problem Based Learning untuk Meningkatkan Kemampuan Berpikir Kritis dan Hasil Belajar Siswa Kelas III. Jurnal Pendidikan: Teori Penelitian dan Pengembangan Volume 3, Nomor 12, 1587-1593. http://journal.um.ac.id/index.php/jptpp/article/download/11799/5607

Nurlaela L. dan Ismayati E. (2015). Strategi Belajar Berpikir Kreatif. Yogyakarta. Pernerbit Ombak.

Redhana, I. W. (2012). Model Pembelajaran Berbasis Masalah Dan Pertanyaan Socratik Untuk Meningkatkan Keterampilan Berpikir Kritis Siswa.Cakrawala Pendidikan, Th. XXXXI, 351-365.

Sianturi, A., Sipayung, T. N., \& Argareta, M. (2018). Pengaruh Model Problem Based Learning (PBL) Terhadap Kemampuan Berpikir Kritis Matematis Siswa SMPN 5 Sumbul,6(1), 2942.

Sugiyono. (2018). Metode Penelitian Kuantitatif, Kualitatif dan R\&D. Bandung: Alfabeta

Sundayana, R. (2016). Statistika Penelitian Pendidikan. Bandung: Alfabeta.

Susanti, E., Muhammad, T., Hidayat, M.T. \& Machmudah. (2019). Kemampuan Berpikir Kritis Siswa SDN Margorejo VI Surabaya Melalui Model Jigsaw. Bioedusiana Volume 4, Nomor 1, 55-64. http://jurnal.unsil.ac.id/index.php/bioed/article/download/792/630

Rahmawati, Faizah, MN, \& Fazila, S. (2014). Pengaruh Penerapan Model Pembelajaran Problem Based Learning (PBL) Terhadap Kemampuan Berpikir Kritis Siswa Kelas V SD. Lentera Vol. 14 No.1, 31-38. https://media.neliti.com/media/publications/148917-ID-problembased-learning-pbl-terhadap-kema.pdf 